\title{
TRAUMA IS THE "STEALING OF MY SENSE OF BEING ME": A PERSON-CENTRED PERSPECTIVE ON TRAUMA
}

\author{
Barbara Wade, Rinie Schenck
}

\section{INTRODUCTION}

Exposure to trauma has always been part of human existence (Marsella, Friedman \& Spain, 1996). Extreme stress has been depicted by authors throughout the ages. In Homer's Odyssey (4 000 years ago) and Shakespeare's Henry VI (1591), for example, portray post-traumatic stress reactions to war (Wade, 2009). In 1993 the American Psychiatric Association (APA) defined trauma in the Third Diagnostic and Statistical Manual (DSM III) as a catastrophic stressor that would evoke significant symptoms of stress in most people. Trauma was thought to be "a rare and overwhelming event, generally outside the range of usual human experiences" (APA, 2000:467). Events that fitted this definition of trauma included rape, assault, incarceration, military combat, accidents and domestic violence. After many debates about the concept of trauma, the definition was changed in the DSM IV to focus not on the event(cause) itself, but on the person's response(effect) to the event or the symptoms the person showed after the event (APA, 2000; Wade, 2009). The APA acknowledged that people give different meanings to events and therefore not all seemingly traumatic events are experienced as traumatic by all people. The DSM IV constructed criteria or symptoms for the condition "posttraumatic stress disorder" (PTSD) to describe the condition in the following way: "The person experienced, witnessed or was confronted with an event or events that involved actual or threatened death or serious injury, or a threat to the physical integrity of self and others" (APA, 2000:467). This definition excludes other events that are not life threatening. The person's symptoms, according the DSM IV, could include intense fear, helplessness or horror (APA, 2000:467). This would imply that events such as the destruction of one's home, or a threat to life, would qualify as being traumatic, but divorce or illness would not qualify if physical threats were not present (Norris, 1992).

Despite the general use of the DSM IV, the value of the criteria described in the DSM IV for PTSD as a basis for the identification of people who have experienced trauma has been questioned (Beaulieu, 2003; Friedman \& Marsella, 1996; Retief, 2004). Stewart and Swartz (2005) also questioned the diagnostic criteria as they exclude those who deal professionally with trauma, e.g. professionals who work with trauma victims like ambulance workers, therapists and police officers. Beaulieu (2003) contends that an event needs not to be catastrophic or a physical threat to result in psychological trauma. She cites verbal abuse of a child as an example. If the verbal abuse is linked with other experiences or if it is an ongoing process, it can be experienced as traumatic as harm will be done to the psychological self to the person.

Another argument was raised by Marsella et al. (1996) is that almost all the theory and research on trauma have been generated by European, American, Israeli and Australian researchers and professionals who share Western cultural traditions. Marsella et al. (1996) further imply that there is a risk of ethnocentricity in trauma research, denying the different meanings people attach to what is trauma and when an incident can be regarded as traumatic. Mokgathle (2001:31) also states that "it would be simplistic to over-generalize and accept that Western psychology is applicable to Africa in all aspects". Friedman and Marsella (1996) point out that 
the subjective appraisal of an event should rather determine whether a person perceives a stressful event as being traumatic or not.

Given the argument about different perspectives on the concept of trauma, the authors facilitated an exploratory research process with fourth-level Social Work students at the University of South Africa (Unisa). This was motivated as the students shared experiences of distressing events and circumstances during supervision and workshops on their practical work. These traumatic events and circumstances, according to the students, affected their lives, changed their perceptions about people and influenced their attitudes and actions towards people as future social workers. Also given the fact of the realities of the prevalence of crime and violence in South African society and that South Africa is regarded as the country with the highest incidence of rape and murder in the world (Stewart \& Swartz, 2005), it was assumed that many of the students might have been exposed to traumatic events. To be able to understand the meanings the students attached to the concept of trauma and the possible effects the traumatic event may have on them as persons and future professionals, two research questions guided the research process. Research questions serve as signposts for the research process (Cresswell, 1998). The following questions were constructed:

- How do the students describe the concept of trauma and what meaning do they attach to the concept?

- What are the effects of the traumatic events on the students as future social workers?

\section{THEORETICAL PERSPECTIVES USED IN THE STUDY}

The theoretical perspectives guiding this study were the person-centred approach and some African perspectives on illness and trauma.

\section{THE PERSON-CENTRED APPROACH (PCA)}

In a multicultural society such as South Africa the challenge facing many researchers is how to facilitate the process to allow all voices, perceptions and experiences of those concerned to be heard. For the authors a person-centred perspective fulfils this need and makes provision for the creation of an unbiased and respectful space where experiences and perspectives can be shared.

Rogers formulated his person centred approach (PCA) or "theory of selfhood" in terms of 19 propositions (1951:481-533). ${ }^{5}$ The theory is based on a belief in a person's constructive potential and intrinsically goal-directed behaviour towards health, growth and adjustment (Prop. 4) (Moore, 1994; Van Dyk, 2000). The approach also emphasises the centrality of the person's subjective experiences (Prop. 1). It proposes that a person experiences and perceives his or her internal and external world in terms of his or her self-concept. Therefore a person is best understood from the perspective of his or her frame of reference (Prop. 2) (Rogers, 1951:494). A person's perception of himself or herself, or his or her self-concept, is formed in interaction with significant others (Props. 8 and 9). The PCA will refrain from labelling a person, but rather refer to "a person who experienced trauma" and not a "victim" of trauma, which dissociates the person from the event and his or her experience of the event (Grobler \& Schenck, 2010).

The "self" of the person determines what experiences and values the person can or cannot allow into his or her conscious mind (Props. 10 and 11). The experiences that threaten the

${ }^{5}$ Further reference is made to these 19 propositions Person centred approach during the discussion of the students' experiences and perceptions. 
person's perception of who he or she is will be denied, ignored or distorted, creating an inner turmoil, with the resulting psychological tension, and the person will thus attempt to protect himself or herself (Prop. 16) (Grobler \& Schenck, 2010). Also, if a person does not know who he or she is (no clear sense of self or identity), or he or she does not know what behaviour fits with him or her, or even which values, the person might be tempted adopt from significant others.

According to the PCA, experiences may become "symbolised" (conscious) or "un-symbolised" (unconscious or beyond conscious awareness), depending on whether they are in accordance with the self-perception of that individual. Regardless of whether experiences are symbolised or not, they have an effect on the self-concept of the person. Symbolisation of experiences is facilitated by a safe empathic context, thus enabling the person to admit the experiences into conscious awareness and accommodating most of these experiences. When this occurs, the person will be at peace with himself or herself, and be able to behave in ways which fit with the new self and develop values that are congruent with the self (Grobler \& Schenck, 2010).

This understanding by the PCA guided the research process and a safe context was provided in which participants could freely share their own experiences of trauma and what the effect of the events were on their perception of self.

\section{THE INFLUENCE OF THE AFRICAN WORLDVIEW ON ILLNESS AND TRAUMA}

The Western perspective on trauma (DSM IV) is one of the perspectives relevant in South Africa. Since culture influences perceptions, meanings and diagnosis (Castillo, 1997), it was deemed important to listen to the other cultural voices in addition to Western descriptions of the concept of trauma.

No descriptions of the concept of trauma were found in the sources consulted on African worldviews, but perspectives on illness and healing were provided. According to Mokgathle (2001), illness, calamity or trauma may be seen as having been sent as a warning or punishment. Thus the origins of trauma are believed to be punishment from the gods, a curse, witchcraft, natural causes, a disruption of social relationships, angered ancestors, possession of evil spirits, or the breaking of customs or taboos. Beuster (1997) also indicates that in African ways of thinking, people may have the belief that the causes of problems can be uncovered. The causes as indicated can be the gods, ancestors, witchcraft, or some form of pollution. The researchers were fully aware that these perceptions cannot be generalised, and that in view of the diversity of the South African population, there may be different thoughts and beliefs about a concept such as trauma.

\section{RESEARCH APPROACH AND METHODOLOGY}

The study to explore the Unisa fourth-level Social Work students' perceptions and experiences of trauma was qualitative and phenomenological in nature. According to Creswell (1998:51), phenomenological research "describes the meaning of the lived experiences ... it explores the structures of consciousness in human experiences". The qualitative data yielded rich descriptions of the concept of trauma from the viewpoint of participants themselves.

According to Mack, Woodsong, MacQueen, Guest and Namey (2005), qualitative research seeks to understand a given research problem from the perspective of the participants. It is also effective in obtaining culturally specific information about the values, opinions, behaviours and social contexts of people. Mack et al. (2005) further state that the strength of qualitative research is its ability to provide complex contextual descriptions of how people experience a 
given research issue. This statement is confirmed by Denzin and Lincoln (2003:5), who say that qualitative and in particular phenomenological research "attempts to make sense of, or interpret phenomena in terms of the meanings people bring to them" This research approach also matched the person-centred approach.

Within this qualitative and phenomenological approach the researchers employed an explorative and contextual research design of inquiry. Marshall and Rossman (2006) regard exploratory research as necessary when we know little about phenomena and when we want to discover the meanings that people attached to concepts, issues, actions and events. A contextual research design was deemed critical as it emphasises both the macro and the micro contexts in which the individual finds himself or herself, like the South African context of pervasive crime in which the students live (Stewart \& Swartz, 2005).

\section{SAMPLING AND SELECTION}

Purposive sampling as a non-probability sampling technique was used. Adams, Dominelli and Payne (2008) refer to purposive sampling as handpicking people for the research, and Abrams (2010) indicates that the researcher decides who will provide the best perspective. All fourthlevel students ${ }^{6}$ during 2006 and 2008 were invited to participate in the research. In 2008 another series of focus groups was facilitated. The 2007 group were not included as Unisa students often complete their fourth level over a period of two years.

Students taking part in the focus group discussions comprised 56\% (128) of the total fourthlevel group concerned. Some of the students indicated that they did not want to participate in the focus group discussions as they thought they might reveal too much about themselves in the presence of their fellow students. According to Rubin and Babbie (2005), a response rate of $50 \%$ in this type of situation is considered adequate; a rate of $60 \%$ good; and a rate of $70 \%$ very good. However, the number of participants is not regarded to be much of an issue in qualitative research, because the aim is to generate a rich description until saturation of information is reached (Fossey, Harvey, McDermott \& Davidson, 2002).

\section{DATA COLLECTION}

The aim of conducting a focus group is to get closer to participants' understanding and perspectives (Kvale, 1994; Millward, 1995; O’Leary, 2005). According to Krueger and Casey (2000), a focus group is a special type of group in terms of purpose, size, composition and procedures. Participants are selected and a permissive environment is created that encourages participants to share experiences. "A focus group study is a carefully planned series of discussions designed to obtain perceptions on a defined area of interest in a permissive non threatening environment" (Krueger \& Casey, 2000:5).

The Department of Social Work at Unisa granted permission to facilitate the focus groups during workshops on trauma for the fourth-level students in five provinces and six regional learning centres. The learning centres were located in Cape Town, Pretoria, Durban, Johannesburg, Polokwane and Bloemfontein. Students from the other provinces attended the workshops in one of these learning centres. Although the attendance at the workshops was compulsory, the students were given the choice whether they wanted to participate in the research. In total 12 focus groups were conducted and recorded.

\footnotetext{
${ }^{6}$ Fourth-level students are students in their final year before entering the profession.
} 
The focus groups were facilitated within a warm and safe environment, where the students were supported and debriefings were offered after the focus groups, if needed. The students gave written permission to participate and for the discussions to be audio recorded.

\section{DATA ANALYSIS}

Krueger and Casey (2000) mention that qualitative analysis is a deliberate, purposeful process. It is systematic, uses verifiable procedures and is done in a sequential manner. The qualitative data were transcribed and analysed using an interpretive method known as hermeneutics. Hermeneutics focuses on discovering meaning in context. The task of hermeneutics is to make something that is unintelligible meaningful and understandable (Addison, 1999). The hermeneutic method does not have a prescribed set of techniques. In this study Terre Blanche, Durrheim and Kelly's (2006) five-step approach was followed.

Step 1 Immersion: The text of the transcribed data was read and re-read to enable the researchers to become thoroughly familiar with the material. The researchers became immersed in the text and were then able to summarise data and identify themes.

Step 2 Developing themes: The themes identified were developed further by seeking contradictions and similarities.

Step 3 Coding: As themes were being developed, the data were coded. Originally the data were coded manually by the researchers, but in view of the large amount of information gathered, the data were analysed using the computer program Atlas Ti.

Step 4 Elaboration: The themes were explored more thoroughly, so that commonalities and discrepancies within the themes could be uncovered. The process was repeated until no new insights emerged and the themes were saturated.

Step 5: Interpretation and checking: This refers to the written account and the reflections of the researchers (Miller \& Crabtree, 1999). The report was compiled and individual accounts and quotes were integrated into the general account as evidence.

\section{FINDINGS OF THE RESEARCH}

The findings of this research are presented in terms of the students' biographical details and the themes identified from their descriptions of the concept of trauma and the effect of the trauma.

\section{BIOGRAPHICAL DETAILS}

The 2006 group comprised of $86 \%$ females and 14\% males, whilst the 2008 group consisted of $83 \%$ females and $17 \%$ males. This corresponds with social work traditionally being an occupation for women (Earle, 2008; Schenck, 2004).

The ages of the students in the 2006 group ranged from 21-65 years, with an average age of 31 , and those in the 2008 group, from 21-57, with an average age of 29 years. This differs from the situation at most residential universities, where the average age of the students on this level is around 22 years (Schenck, 2009). It may be that the students who participated in the research may have had more life experiences and exposure to trauma than students from residential universities.

In 2006 74\% of the fourth-level Social Work students at Unisa were black, 17\% white, $7 \%$ Indian and $2 \%$ coloured. In 2008 there were $78 \%$ black, 14\% white, 5\% Indian and 3\% coloured students. 
The marital status of the students was almost similar in both the groups with $61 \%$ single, $32 \%$ married (customary and legal marriages), 3\% divorced, 3\% cohabitating and 1\% widowed. Forty-seven per cent $(47 \%)$ of the students were employed, thus they had additional family and career responsibilities.

\section{STUDENTS' DESCRIPTION OF THE CONCEPT OF TRAUMA}

This section focuses on what the participants regarded as the core distinguishing features of a traumatic experience. They shared what had happened to them personally in order to explain the concept. In subsequent research with the same group, it was determined that every one of the students had experienced a traumatic event. Furthermore, uniquely South African experiences were mentioned, like those involving "kangaroo courts", 7 taxi violence, "necklacing" and dealing with ancestors. The transcribed responses are quoted verbatim and the themes that were identified are discussed below, supplemented with support from the literature.

\section{- Theme 1: Trauma invades one's life and affects the whole person}

One of the main themes the students mentioned was that the traumatic experience invades one's whole life, way of being and in particular the self of the person. This was deduced from the following quotations:

"It is an incident that invades your private space and has an impact on your life in such a manner that it influences your normal day-to-day life. It leaves you feeling helpless without control.”

"Trauma is an experience that creates a wound in someone's soul and it affects them emotionally, psychologically and physically."

"It hijacks your emotions and your feelings at that time of the incident."

"Trauma is a very destructive disease. It takes over the entire being and breaks you as a person bit by bit."

To confirm their description of trauma as wounding the person, the participants indicated the difference between stress and trauma. Stress was described as coming from outside, while trauma came from the inside. The person's experience that trauma is "wounding the inside" was expressed as follows by a participant:

"Trauma is a personal violation - physically and psychologically."

These descriptions link with the PCA (Prop. 3), which refers to the fact that people react holistically to experiences. All dimensions of a person - feelings, thoughts, values, emotions, behaviour and physical attributes - form an organised whole (Grobler \& Schenck, 2010; Rogers, 1951). It also refers to the core of the PCA (Prop. 8), which relates to the forming of the self of the person and the fact that the incident threatens or wounds the self of the person it affects the way one thinks about oneself (Grobler \& Schenck, 2010; Moore, 1994; Rogers, 1951; Wade, 2009) as emerged in theme 2.

\footnotetext{
${ }^{7}$ A kangaroo court is a self-appointed or mob-operated court.

${ }^{8}$ Necklacing is the practice of summary execution carried out by forcing a rubber tyre, filled with petrol, around a victim's chest and arms, and setting it on fire. The victim may take up to 20 minutes to die, suffering severe burns in the process.
} 


\section{- $\quad$ Theme 2: Trauma distorts the perception of the self}

The students mentioned that trauma is experienced as injuring, deforming and distorting the self. The self is left "feeling infected", described by participants as follows:

"For me trauma is a wounding of the mind."

"You see yourself as a piece of something ... not a human being."

"The self has been twisted and turned - infested with the perpetrator."

"Being raped stole my sense of being me."

The theme of the self of the person being threatened and distorted emerged strongly. Implied in this theme also is the theme of loss: loss of sense of the self and of being a human being. You lose yourself and who you are. Rogers's Prop. 9 indicates that one builds up perceptions about oneself from infancy as one interacts with the environment and with other people (Rogers, 1951). Trauma distorts the perception we have about ourselves. It seems as if it is the discrepancy regarding the self rather than the incident itself that makes the event traumatic. For example, emergency workers, paramedics and fire fighters may be exposed to incidents that are painful and distressing. However, they experience this as "I am here to help" (Friedman 2006). This is in line with their idea of their selves. If the person experiences helplessness and vulnerability and is unable to save another person or himself or herself, the event may be experienced as traumatic and the experiences of the self will be distorted (Baumeister, 1995; Wade, 2009). Baron and Byrne (2000) argue that the greater the discrepancy between the idea of the self and the experiences ("This could not have happened to me"), the more traumatic it might be for the person. This argument is elaborated further in the next theme.

\section{- $\quad$ Theme 3: Trauma leaves one feeling powerless and vulnerable}

The experience of being helpless and powerless as a result of trauma is expressed by the DSM IV (APA, 2000). Experiencing powerlessness, meaning not being able to do anything about the situation, intensifies the trauma. Participants expressed themselves as follows in this regard:

"Witnessing a close friend of mine being mugged - not having the power to protect her, being helpless ...”

“... the vulnerability ... you find yourself helpless, you cannot do anything; you are out of control."

"At home we could not support ourselves and slept without food. The worst part was when children at school bullied me and talked about how poor we were at home."

Matsakis (1996) confirms that trauma brings to the fore experiences of powerlessness and vulnerability. The participants particularly highlighted experiences of helplessness and powerlessness to illustrate the difference between stress and trauma as follows:

"Stress ... has a solution, while with trauma you are trapped."

The participants viewed poverty as a traumatic stressor. In the following words of participants, this seems to relate to a sense of being powerless if one is poor:

"Poverty traps you."

"I am unemployed, nê; I am stressed because I'm unemployed. If I get a job, the stress can disappear. But with trauma, it is something different."

"It is an experience that leaves the victim feeling hopeless, helpless and filled with horror, anxiety and fear." 
Helplessness can also be intensified by the idea that the trauma was caused by the ancestors, according to statements from some of the participants made in this regard.

"Sometimes if a traumatic event has happened, you go to the grave and talk to the ancestors. Yes, some people might think that the ancestors might protect them. At the same time, they can even view the ancestors as the ones who are causing the traumatic event ... You become more traumatised because you can't go to the person and say, 'Well, what you are doing here is traumatic to me.' You don't know how to sort this thing out; it's like beyond your control."

Naparstek (2006:64) confirms that the impact of trauma is mediated by the degree of control one perceives oneself to have. The participants described regaining control as "finding answers" or "finding solutions" - knowing what to do about the problem and gaining control. This suggests that one of the core features of trauma is that it is a threat to one's self, of being a person in control of one's self, and one's capacity to solve something and regain control of one's self. Rogers' Prop. 4 (Rogers, 1951) suggests that people are motivated to preserve or protect and actualise the self. The inability to regain control in a traumatic situation seems to be experienced as the inability to preserve, protect and actualise the self. The person's constructive potential and intrinsically goal-directed behaviour towards health, growth and adjustment (Prop. 4) has been thwarted. The self has been violated (Prop. 11c) (Grobler \& Schenck, 2010; Moore, 1994; Rogers, 1951).

\section{- $\quad$ Theme 4: Trauma is painful and the pain is persistent}

The students indicated that one of the defining characteristics of trauma is that it is painful. They used metaphors of injury or disease to describe it.

"Trauma is a wound or painful experiences that you will never forget."

"Trauma is a life-changing experience that causes you to bleed inside."

"It is like a wound that destroys your inner being. It destroys your relationship with other people and even with yourself."

"Trauma is a painful experience that recurs ... gives terrible disease which doesn't go away."

The on-going nature of the pain as well as the experience of not being able to do something about it was emphasised. According to them, it is there, you have to live with it. Naparstek (2006) also suggests that the experience of pain includes mourning lost innocence, lost childhood, lost hopes and dreams of a safe world, loss of faith and trust in humankind, and the loss of the idea of the self. Rogers (1990) explains that when experiences are threatening to the self, we may not allow ourselves to symbolise them (Prop. 11), meaning that we may deny or distort the experiences, or that we could be unaware of them. This can create psychological tension and lack of control of the unconscious experiences (Prop. 14) as described in the next theme.

\section{- $\quad$ Theme 5: Traumatic memories emerge uninvited (flashbacks)}

The DSM IV (APA, 2000) indicated flashbacks as one of the symptoms of PTSD. The participants shared that just as the trauma itself is beyond the control of the person, traumatic memories are not recalled at will, but emerge uninvited. This perpetuates the sense that one has lost control. They experience a reliving and re-experiencing of the pain. This reliving of trauma is distinct from remembering. 
A student from KwaZulu-Natal described an incident that had remained vivid in his mind as follows:

"We came on duty and got an incident of shooting in a particular area. As we got to the scene, we found about twenty-three people hacked to death along the road of about two kilometres. We found them along the entire road about a few metres apart. They were sort of chopped in layers. The last person was a child. She was about a year. Although she was dead, her eyes were open. I can still see her looking at me."

Another student described the persistent painful memory:

"It (memories) is something forced into your mind. It is not there because you want it there or you want to have it in your memory or in your database, it is something like a virus that is not supposed to be on your computer system. So what happens is the same way a virus will slowly start to eat every programme in your mind and it affects the functioning of you."

It was further mentioned that a peculiar feature of the traumatic event is that it has the capacity to remain latent and may be triggered unexpectedly:

"I was hijacked and it only came out two years later that I was suffering from posttraumatic stress. The day afterwards, I got into another car and I drove off like nothing happened, and two years later ..."

Studies by Van der Kolk, Hopper and Osterman (2001) and Le Doux (1994) demonstrated that memories of everyday events and those of frightening events are processed differently. The memories and the uncontrollability of the memories threaten the self and leave the person vulnerable as the person never knows when the memories will emerge again.

\section{- Theme 6: A core feature of a traumatic stressor is unpredictability: living with fear and being haunted}

According to the participants, the outcome of traumatic events is unpredictable and the unpredictability creates uncertainty, fear and anxiety. Naparstek (2006) states that the greater the uncertainty, the greater the potential to destroy a sense of control and sense of self.

Besides the incident being experienced as traumatic, it is also the "causative" factors that may intensify the fear; a student articulated this as follows:

"My neighbour was bombed and the grandparents and two grandchildren died. My family was suspected (as the perpetrators) and we were living in fear because that family promised that they would take revenge ... We live in fear that something might happen anytime."

One student described how her family was traumatised by being told by a traditional healer that they would all die.

Another traditional healer told the family whose mother had died that the mother had become a "zombie". We understood that the belief is held that a person's spirit may not depart to be with the ancestors, but may wander in a lonely in-between state as one of the "living dead". The students said there are no rituals to ward this off, emphasising their experience of powerlessness:

\footnotetext{
${ }^{9}$ In the PCA the focus is not causative factors, while in an African worldview causative factors might be regarded as important.
} 
“... my mother-in-law died in December ... the family are consulting inyangas (traditional healers). They (the inyangas) are saying that she is somewhere behind the door with this big snake! They say 'Your mother is behind the door with this big snake and her tongue has been cut off so that she must not talk (cannot talk' ... then the inyanga said, 'OK fine, I am going to help you.' Then the questions are: How are (you) going to help us? Are you going to kill the person or bring him back? ... when you bring back the person, are we not going to be scared because we saw that person lying in the coffin!"

"In my Pedi culture if he (grandfather) passed away when he was 93 years old ... he had lived his life! ... so when my mother is still grieving, some other people are going to the sangomas (traditional healers) and they will tell you, 'Ah no, no he is not dead that person, that person might be a zombie somewhere.'."

Participants emphasised that their cultures vary and that they themselves did not necessarily hold traditional beliefs. They also expressed appreciation for some of their cultural practices, but acknowledged the fact that some of the practices can intensify the trauma.

\section{- $\quad$ Theme 7: Trauma changes one's perceptions and belief systems}

It may be deduced from the following quotations that a change in self-perception may also bring a change in the belief system of the person:

"Trauma brings with it a strong feeling that leaves you shaking to the core of your being. It changes the way you look at life, people around you, yourself and the systems of government."

"Trauma slowly undermines and breaks the individuals' self and their values, and negatively affects the individual."

"Trauma changed my behaviour and perception of the world I live in. I kept on hearing this voice in my head which made it bad for me to live in this world. I just wanted to isolate myself from people."

"My grandmother, about 80 years, was raped in the fields by 15 young boys ... and thrown in a ditch still alive. She landed in ICU when found and died a few hours later. Men are now changed into creatures which women have to fear."

The participant's perceptions were that trauma is caused by an event that alters convictions and shatters perceptions. This is similar to the findings of Janoff-Bulman and Frieze (1983), who suggest that being victimised disturbs one's belief in the fundamental goodness of people, the benevolence of the world and the view of the self as being invulnerable. A person who is traumatised is confronted with a sense of his or her vulnerability, leaving the person afraid that the incident could occur again (Matsakis, 1996).

As one student explained:

"... it makes you anxious ... that frightened feeling in the stomach, and you start sweating and shivering. You become anxious - you feel like you want to run away - if you maybe sit in a taxi and you hear a voice and it sounds like the voice of the perpetrator, you want to get out ..."

“... you are still living it each day ..." 
In addition to the change in their belief system, some of the students indicated that after the traumatic experience, they now tend to stereotype:

An Ndebele student was mugged by two Zulu men:

“... I have a problem with Zulu men ... they are born to do crime."

Female students who experienced rape, or physical and sexual abuse commented:

"Most men are cruel."

"Every man is a potential rapist."

"My husband was pointing a gun at me and shooting the wardrobe, choking me and throwing things at me. I see all men as being useless."

"When I was molested ... Men are nothing but a piece of $s^{* *} t$."

"I am wary of people, always watching my back; also I mistrust other (people)."

One mentioned that her mother left her, never to return:

"I hate all those mothers who allow their children to be raised by a stepmother, because you do not know how that child is treated."

These examples could illustrate efforts to protect the self from any person who might threaten the self again.

A participant commented as follows:

"Other experiences build relationships, but trauma ruins relationships."

The last comments, in particular, created concern about the students as future social workers. A social worker's distorted perception of a client can make it impossible for him or her to accept the client fully. Rogers (1967) concluded that the attitude of the facilitator, rather than his or her theoretical orientation, was a crucial component in making the relationship detrimental or useful to the person needing help. Social workers struggling with stereotyping may find it difficult to establish a warm relationship in which the client may disclose his or her deepest, darkest secrets. Rogers (1967) explains that when a person is unable to accept the client fully, it is because the person's self is threatened in some way by what the person has brought into the session. This indicates that some participants may be struggling with un-symbolised threats within themselves.

Behaviour is goal directed (Prop. 5) and stereotypes may serve to protect the self of the social worker, as defensive behaviour serves to protect the self (Prop. 16), but might be detrimental to the clients of the facilitator (Grobler \& Schenck, 2010).

\section{- $\quad$ Theme 8: Alienation and numbness}

The students shared their feelings of alienation and disconnectedness by expressing themselves as follows:

"The pain is so great that you detach from yourself - you do not own your body and you have no real feelings."

"You learn to dissociate."

"My father committed suicide when I was nine ... my whole life collapsed, I went into like a sleep phase ... until about Standard 6 (Grade 8)." 
According to the DSM IV (APA, 2000), numbness is one of the symptoms of trauma. In the study on the traumatic experiences of ambulance staff (Stewart \& Swartz, 2005) numbness was one of the most common symptoms expressed by the ambulance workers. The ambulance workers said that they were "unable to feel emotions." Stewart and Swartz (2005) further mentioned that emotional numbness was contradicted in the individual interviews, where the participants could reflect on and acknowledge their emotions in safe environment (Grobler \& Schenck, 2010; Rogers, 1951).

\section{- $\quad$ Theme 9: Trauma is intensified by other factors}

This theme emerged consistently in the discussions with the students who said that they experienced many factors that intensified the trauma.

\section{BETRAYAL}

Those who experienced trauma due to incidents such as sexual molestation added that the betrayal factor had intensified the trauma.

"When I was 12 years old I was sexually molested by my father. This was very traumatic to me, because I trusted him and loved him."

"My worst experience was being traumatised by people who you think are the ones who are meant to help you."

In a similar vein another student told what the father of her children did after their separation:

"He did something that I never thought he would do; burning two microbuses of my parents ... I was the one who heard the cars exploding ..."

\section{DEHUMANISATION}

Dehumanisation of the victim intensifies the trauma, as explained by the students who were hijacked, kept captive in the boot of a car, and another who experienced rape.

“... can you imagine having to go to the toilet and you can't, you are in a car boot? You are not fed; you are not given water, anything ..."

“... it is the level of violation, because with the rape scenario, what really happened is this person was violating your inner being - it is a physical attack on yourself."

\section{SILENCING}

Other students indicated that the silencing factor intensifies the trauma. As one stated:

"I was molested when I was 10 years old and when my mother found out at a later stage, my father denied that incident. My family looked at me like an unworthy child who wanted to separate the family. My grandmother said we must keep it to the family and not involve the police."

\section{EXONERATION OF PERPETRATORS THROUGH RITUALS}

Students also explained that in some communities the perpetrator may be exonerated by performing a ritual and paying compensation to the family, while the victim is left suffering in silence. They referred to this reality as follows:

"Our culture ... you know, when people like a father, rapes his daughter, or an uncle sodomises his nephew, then they call it ishlazo (a disgrace). So to minimise the incident, that person can pay by performing some sort of ritual, because the ancestors are now angered, but the survivor of that, can't get nothing there!" 
Another student explained further:

“... mainly in the rural areas, they don't like the thing to be exposed, you know - they just like to keep everything in the family ... The person should pay in order to cleanse that person. Usually you pay a sheep, saying that you're cleansing the family. But then it still doesn't make it right."

"Paying things does not resolve the trauma to the child. It just resolves the trauma to the family. They do not care about the child ... it's just that some cultures are ignorant about dealing with trauma with the child."

The study by Valor-Segura, Exposito and Moya (2011) argues that the exoneration of the perpetrator is often based on gender-biased ideologies.

\section{BLAMING THE VICTIM}

The effects of blaming the victim in relation to a traumatic experience were pointed out. Blaming the victim intensifies the trauma, as stated by a student who had been mugged.

“... they perceive you as weak ... why didn't you fight back?”

Blaming the victim and twisting the story:

"After a car accident I was involved in, my face became scarred ... others were gossiping, saying I was involved with someone's husband and that person stabbed me with a knife."

Blaming the victim linked with the causative factor:

"In my culture ... let us say that I am the husband of somebody and I die now through a car accident. Generally you find that they blame the wife, saying that she bewitched me, you understand?"

Gender bias:

“... they will be thinking that maybe the wife killed the husband so that she can be rich and then enjoy herself with other men, but if it is the wife who is dead, the men are not blamed at all."

The gender-based ideologies noted by Valor-Segura et al. (2011) are confirmed here.

\section{DISRESPECT INTENSIFIES TRAUMA}

Another aspect the students mentioned was that insincerity and gossip add to the trauma. The following example was given when somebody is in the process of divorcing:

“... they (neighbours, friends) came in - they were just fishing for information. Then they were taking this information, spreading it ... spiced it up and then it was ... wow ... just a big ball of fire ... I reached a point where I broke down."

"They love indaba (discussion). They can come to you all nice, like 'Ah, I mean so sorry.' ... they go outside - shouting your business! "”

\section{CREATING MORE FEAR}

It seems that the belief that deceased people are transformed into zombies can create more fear on top of the trauma. One of the students explained it as follows:

“... Ja, you understand ... this is another trauma on top of the other one." 
Matsakis (1996) warns that people who do not understand the traumatised person's situation may be cruel and insensitive. She refers to this as "secondary wounding". People may respond with disbelief, denial or discounting the incident.

In principle, all the intensifying factors entail disrespect towards the person and are a threat to the self, which intensifies the trauma. In contrast, the PCA suggests that a climate of respect is crucial and that it is vital to create an unconditional, accepting and safe environment in which the self may be explored (Grobler \& Schenck, 2010).

It seems that all these elements include other people who play a significant role in participants' lives, and in interaction with them the participants tended to develop a sense of being worthless or not worthy of respect and consideration.

\section{CONCLUSION}

This article reported on an exploration of the perceptions and experiences of trauma of fourthlevel Social Work students at Unisa. The students shared their lived experiences and perceptions of trauma. Many of the symptoms expressed by the students relate to the symptoms for PTSD as described by the DSM IV, e.g. numbness, feeling on guard, recurring fears and thoughts, feeling that people do not understand what is happening to you, and experiences of betrayal (Stewart \& Swartz, 2005).

The main difference from the DSM IV that emerged from this study is the overarching theme of trauma as the wounding of the psychological self, that the sense of being me is stolen; what is left is the distorted self and the question of "Who am I now after the trauma?" Events wounding or violating the psychological self of the person are experienced as traumatic. They may not know who they are anymore and do not trust their own values and inner voices. Trauma is an experience that undermines the sense the self and its existing values; it is a threat and wounds the self, causing intense pain. The intrusive nature of trauma leaves the person powerless and vulnerable, as he or she does not know when the traumatic experiences will reemerge. Disrespect, blaming and silencing the person, as well as cultural beliefs and practices (irrespective of the culture) may intensify the trauma and the threat to the self. The perception that one is in the grip of powerful forces over which one has no control intensifies the pain (wound) and feelings of powerlessness and vulnerability. These factors contribute to the experience that the person's "sense of being me" was stolen. The students provided an enriched description of trauma that can be useful in understanding trauma from a person-centred perspective.

This study also touched on issues that could be investigated further. It raised questions about the wellbeing of the students involved and the effect the trauma may have on them as future social workers. The relationship between the students' experiences and throughput rates at universities needs to be examined. Furthermore, there is the question of the responsibility of the universities and in particular all departments of social work to explore the students' wellbeing and to offer support to the "wounded healers". Le Croy $(2002: 149)$ states that it might be important to help the students to "develop their true selves and find a greater connection between their work and their existence in the world".

\section{REFERENCES}

ABRAMS, L.S. 2010. Sampling "hard to reach" populations in qualitative research: the case of incarcerated youth. Qualitative Social Work, 9(4)536-550. 
ADAMS, R., DOMINELLI, L. \& PAYNE, M. 2008. Social Work research for social justice. Hampshire: Palgrave.

ADDISON, R.B. 1999. A grounded hermeneutic editing approach. In: CRABTREE, B.F. \& MILLER, W.L. (eds) Doing qualitative research $\left(2^{\text {nd }}\right.$ ed). Thousand Oaks: Sage Publications.

APA (AMERICAN PSYCHOLOGICAL ASSOCIATION). 2000. Diagnostic and Statistical Manual of Mental Disorders $\left(4^{\text {th }}\right.$ ed). Text Revision DSM IV - Tr. Published by the American Psychiatric Association. Washington. DC: 467-468.

BARON, R.A. \& BYRNE, D. 2000. Social Psychology $\left(9^{\text {th }}\right.$ ed). Massachusetts: Allyn and Bacon.

BEAULIEU, D. 2003. Eye movement integration therapy. Williston: Crown House Limited.

BEUSTER, J. 1997. Psychopathology from a traditional African perspective. Unisa Psychologia, 24(2):5-16.

BAUMEISTER, R.F. 1995. Self and identity: an introduction. In: TESSER, A. (ed) Advanced social Psychology. Boston: McGraw-Hill.

CASTILLO, R.J. 1997. Culture and mental illness: a client-centred approach. Pacific Grove: Brooks Cole.

CRESWELL J.W. 1998. Qualitative inquiry and research design: choosing among five traditions. Thousand Oaks: Sage Publications.

DENZIN, D. \& LINCOLN, Y.S. 2003. The landscape of qualitative research: theories and issues. Thousand Oaks: Sage Publications.

EARLE, N. 2008. Social work in social change: the profession and education of social workers in South Africa. HSRC. Research monograph.

FOSSEY, E., HARVEY, C., McDERMOTT, F. \& DAVIDSON, L. 2002. Understanding and evaluating qualitative research. Australian and New Zealand Journal of Psychiatry, 36:717732.

FRIEDMAN, M.J. \& MARSELLA, A.J. 1996. Post-traumatic stress disorder: an overview of the concept. In: MARSELLA, A.J., FRIEDMAN, M.J., GERRITY, E.T. \& SCURFIELD, R.M. (eds) Ethno cultural aspects of post-traumatic stress disorder: issues, research and clinical applications. Washington: American Psychological Association.

FRIEDMAN, M.J. 2006. Post Traumatic and acute stress disorders. Kansas: Compact Clinicals.

GROBLER, H.D. \& SCHENCK, C.J. 2010. Person centred facilitation: process, theory and practice. Cape Town: Oxford University Press.

JANOFF-BULMAN, R. \& FRIEZE, I. 1983. A theoretical perspective of understanding reactions to victimization. Journal of Social Issues, 39:2.

KRUEGER, R.A. \& CASEY, M.A. 2000. Focus groups: a practical guide for applied research. Thousand Oaks: Sage Publications.

KVALE, S. 1994. Ten standard objections to qualitative research interviews. Journal of Phenomenological Psychology, 25(2):147-173.

LE CROY, C.W. 2002. The call to Social Work. Thousand Oaks: Sage Publications. 
LE DOUX, J.E. 1994. Emotion, memory and the brain. Scientific American, 270(6):50-57.

MACK, N., WOODSONG, C., MacQUEEN, K.M., GUEST, G. \& NAMEY, E. 2005. Qualitative research methods: a data collectors field guide. USAID.

MARSELLA, A.J., FRIEDMAN, M.J. \& SPAIN, E.H. 1996. Ethno-cultural aspects of post traumatic stress disorder: an overview of issues and research directions. In: MARSELLA, A.J., FRIEDMAN, M.J., GERRITY, E.T. \& SCOURFIELD, R.M. (eds) Ethno-cultural aspects of post traumatic stress disorder: issues, research and clinical applications. Washington. American Psychological Association.

MARSHALL, C. \& ROSSMAN, G.B. 2006. Designing qualitative research. Thousand Oaks: Sage Publications.

MATSAKIS, A. 1996. I can't get over it: a handbook for trauma survivors $\left(2^{\text {nd }}\right.$ ed). Oakland CA: Harbinger.

MILLER, W.L. \& CRABTREE, B.J. 1999. The dance of interpretation. In: CRABTREE, B.J. $\&$ MILLER, W.L. Doing qualitative research $\left(2^{\text {nd }}\right.$ ed $)$. Thousand Oaks: Sage Publications.

MILLWARD, L.J. 1995. Focus groups. In: BREAKWELL, G.M., HAMMOND, S. \& FIFESHAW, C. (eds) Research methods in Psychology. London: Sage Publications.

MOKGATHLE, B. 2001. Psychopathology from an African perspective. Only study Guide for PYC 302: abnormal behaviour and mental health. Pretoria: Unisa.

MOORE, C. 1994. Carl Rogers' self concept theory. In: MEYER, W.F., MOORE, C. \& VILJOEN, H.G. (eds) Personality theories from Freud to Frankl. Isando: Lexicon.

NAPARSTEK, L.W. 2006. Invisible heroes: survivors of trauma and how the heal. London: Piatkus.

NORRIS, F.H. 1992. Epidemiology of trauma: frequency and impact of different potentially traumatic events on different demographic groups. Journal of Consulting and Clinical Psychology, 60(3):409-418.

O'LEARY, Z. 2005. Researching real world problems: a guide to methods of inquiry. London: Sage Publications.

RETIEF, Y. 2004. Healing for trauma. Cape Town. Struik.

ROGERS, C. 1951. Client centered therapy: its current practice, implications and theory. London: Constable.

ROGERS, C. 1967. On becoming a person: a therapists view of psychotherapy. London: Constable.

ROGERS, C. 1990. The Carl Rogers reader. London: Constable.

RUBIN, A. \& BABBIE, E. 2005. Research methods for Social Work $\left(5^{\text {th }} \mathrm{ed}\right)$. Pacific Grove: Brooks/Cole.

SCHENCK, C.J. 2004. Working conditions of Social Workers in rural areas in South Africa. The Social Work Practitioner Researcher, 16(2):191-199.

SCHENCK, C.J. 2009. The socio-economic realities of the Social Work students of the University of South Africa. Social Work/Maatskaplikewerk, 45(3):299-313. 
STEWART, J. \& SWARTZ, L. 2005. Post traumatic stress symptoms in emergency service ambulance personnel. Social Work/MaatskaplikeWerk, 41(4):361-377.

TERRE BLANCHE, M., DURRHEIM, K. \& KELLY, M. 2006. First steps in qualitative data analysis. In: TERRE BLANCHE, M., DURRHEIM, K. \& PAINTER, D. (eds) Research in practice $\left(2^{\text {nd }}\right.$ ed). Cape Town: University of Cape Town.

VALOR-SEGURA, I., EXPOSITO, F. \& MOYA, M. 2011. Victim blaming and exoneration of the perpetrator in domestic violence: the role of beliefs in a just world and ambivalent sexism. The Spanish Journal of Psychology, 14(1):195-206.

VAN DER KOLK, B.A. HOPPER, J.W. \& OSTERMAN, J.E. 2001. Exploring the nature of traumatic memory: combining clinical knowledge with laboratory methods. In: FREYD, J.J. \& DE PRINCE, A.P. (eds) Trauma and cognitive science: a meeting of minds. Science and human experience. Place unknown: Haworth Press.

VAN DYK, A.C. 2000. Introduction to Social Work and the helping process. Only study Guide for SCK 102X. Pretoria: Unisa.

WADE, B. 2009. Unisa Social Work students' experiences of trauma: an exploratory study from a person centred perspective. Pretoria: Unisa. (Unpublished DPhil thesis)

Dr Barbara Wade, social worker in private practice and doctoral student, University of South Africa; Prof Rinie Schenck, Department of Social Work, University of the Western Cape, South Africa. 